\title{
Application of Immunofluorescent Antibody Technique in Rapid Diagnosis of Respiratory Syncytial Virus Infection
}

\author{
P. S. GARDNER,* M.D., DIP.BACT. ; JOYCE MCQUILLIN,* B.SC., F.I.M.L.T.
}

[With Special Plate facing Page 340 ]

Brit. med. f., 1968, 3, 340-343

\begin{abstract}
Summary : Seventy-eight unselected children under $\mathcal{H}$ the age of 2 years suffering from acute respiratory infections were investigated by the fluorescent antibody technique and a comparison was made with conventional isolation and serological methods. Sixty-nine per cent. of children with bronchiolitis were diagnosed as suffering from respiratory syncytial virus infection on the day of admission by examination of nasopharyngeal secretions. There were 44 children with respiratory syncytial virus infection diagnosed by conventional methods over a month, but by using fluorescent antibody techniques on tissue culture $53 \%$ were diagnosed by the second day, $71 \%$ by the fourth day, and $82 \%$ by the seventh day. The method of choice for a rapid diagnosis of respiratory syncytial virus infection is by examining nasopharyngeal secretions, when $90 \%$ of those with this infection can be diagnosed on the day of admission to hospital.
\end{abstract}

\section{Introduction}

In recent months a number of workers have used immunofluorescent techniques for the rapid diagnosis of acute respiratory virus infection. If these are to play a reliable part in diagnostic virology it is necessary to show that the results obtained are confirmed by the established procedures.

Hers et al. (1968) investigated influenza A and used sputum and necropsy material for direct immunofluorescence, as well as monkey kidney tissues and organ cultures of human origin. They confirmed the reliability of their results by the isolation of virus and the demonstration of a fourfold rise in antibody titre to the virus. Two further groups of workers have used immunofluorescent techniques for the early diagnosis of respiratory syncytial virus (Gray et al., 1968 ; McQuillin and Gardner, 1968). Gray et al. used smears made from cough swabs and based the confirmation of their results on a combination of virus isolation and the presence of antibody in the blood. McQuillin and Gardner used nasopharyngeal secretions in a few cases, but the rest were tissue cultures inoculated with specimens. They confirmed their results by virus isolation.

This communication gives results from further investigations with this technique in 78 children with acute respiratory disease. As in our initial study, we used immunofluorescent techniques on inoculated tissue cultures and also nasopharyngeal secretions, when the latter were available. The confirmation of results was based on virus isolation and on the demonstration of increased antibody titres in paired sera, although these were not always available from the very young children.

The period of investigation was from October 1967 to March 1968 , and we have included the 16 patients described in our previous communication. It is intended to show that the methods used give results as reliable within the first week as

\footnotetext{
* Department of Virolozy, Royal Victoria Infirmary, Newcastle upon Tyne 1
}

conventional methods may in a month, and also to show that the results obtained from the examination of nasopharyngeal secretion taken on the day of admission give comparable results with isolation techniques.

\section{Materials and Methods}

The methods and materials were basically the same as those already described (McQuillin and Gardner, 1968). Only modifications and additional procedures are described below.

Respiratory Syncytial Virus Rabbit Antiserum.-Every batch of serum used was tested for non-specific fluorescence against uninfected human cells and against cells infected with viruses other than respiratory syncytial virus. Some sera had to be absorbed two or three times before they were satisfactory. The serum was titrated and tested at various dilutions in phosphate-buffered saline to find the optimum titre for fluorescence against respiratory syncytial virus.

Fluorescein-conjugated Anti-rabbit Globulin (Fluoroscan Plus). -Fluoroscan Plus is an anti-rabbit fluorescen: antibody reagent supplied to us by Winthrop Biologicals Limited. Antiserum against rabbit gammaglobulins is prepared in the dog and purified before conjugation with fluorescein isothiocyanate, isomer I (F.I.T.C.). The conjugated gammaglobulin is passed through Sephadex G-25 (coarse grade) to remove all traces of free fluorescein derivatives. Measurement of the optical density at 495 and $280 \mathrm{~m} \mu$ gives a ratio of 0.6 for the conjugate (Brighton, 1966). This is equivalent to a presumptive F.I.T.C.-protein ratio of $4.7 \mu \mathrm{g}$. of fluorochrome per mg. of protein. Naphthalene black is added to a final concentration of $2 \mathrm{mg} . / \mathrm{ml}$. of conjugate. This acts as a counterstain for suppression of non-specific staining. Fluoroscan Plus gives best results when used under blue light conditions.

Isolation and Identification of Respiratory Syncytial Virus.Cough swabs were collected in Hanks's medium containing $2 \%$ bovine albumin and antibiotics. They were transported in ice to the laboratory and immediately inoculated into tubes of Bristol $\mathrm{HeLa}$, HEp.2, rhesus monkey kidney, and W.I.38 tissue culture cells. The Bristol HeLa and HEp. 2 cells were maintained in Mediun 199 with $2 \%$ foetal calf serum and were incubated in stationary racks at $37^{\circ} \mathrm{C}$. The rhesus monkey kidney and W.I.38 cells were incubated at $33^{\circ} \mathrm{C}$. in a roller drum for the isolation of influenza virus, parainfluenza virus, and rhinovirus. A $10 \%$ suspension of the nasopharyngeal secretions in Hanks's medium containing $2 \%$ bovine albumin was also inoculated into the same system of tissue culture cells for examination by conventional culture techniques. The tubes were examind daily for cytopathic effect, and were fed with fresh medium on every third day. The day on which the typical cytopathic effect of respiratory syncytial virus was first observed is the recorded day of isolation. The virus was positively identified as respiratory syncytial virus by confirmatory neutralization tests with standard respiratory syncytial virus neutralizing antiserum in tissue culture and by the fluorescent antibody technique. In most cases several days elapsed between the first observation of cytopathic effect and the stage when the virus was sufficiently established for a neutralization test to be carried out. The confirmation by fluorescent antibody technique could be carried out on the cells from a tissue culture tube on the same day as the appearance of cytopathic effect, as previously described (McQuillin and Gardner, 1968). No false-positives occurred at any time, and we consider that the 


\section{P. S. GARDNER AND JOYCE MCQUILLIN: APPLICATION OF IMMUNOFLUORESCENT ANTIBODY TECHNIQUE}

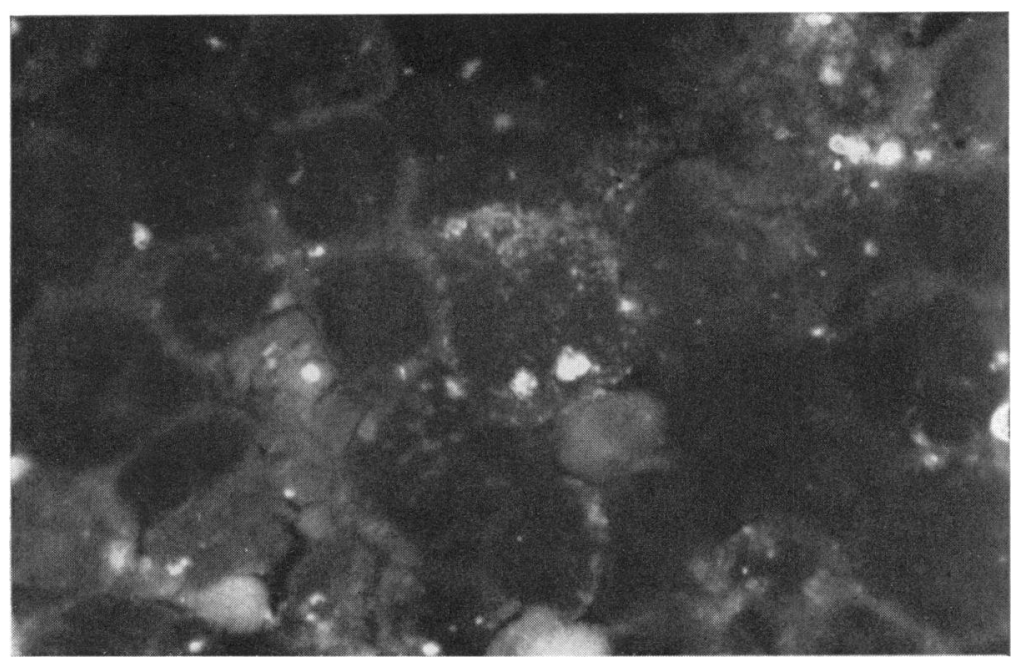

Figs. 1, 2, and 3 are examples of specific fluorescence of respiratory syncytial virus in the cytoplasm of HEp.2 cells at various stages of development. They were stained by the indirect immunofluorescent staining method with respiratory syncytial virus specific antiserum and Fluoroscan Plus. $(\times 333$.

FIG. 1

Fig. 1.-Early fluorescence restricted to single cells with fine fluorescent particles as well as some inclusion-like bodies. FIG. 2.-Increased intensity of particulate fluorescence. FIG. 3.-Later stage with many intensely staining inclusion-like bodies.

All uninfected HEp.2 cell controls stained with respiratory syncytial virus antiserum and Fluoroscan Plus and infected cell controls stained with normal rabbit serum and Fluoroscan Plus showed a complete absence of fluorescence.

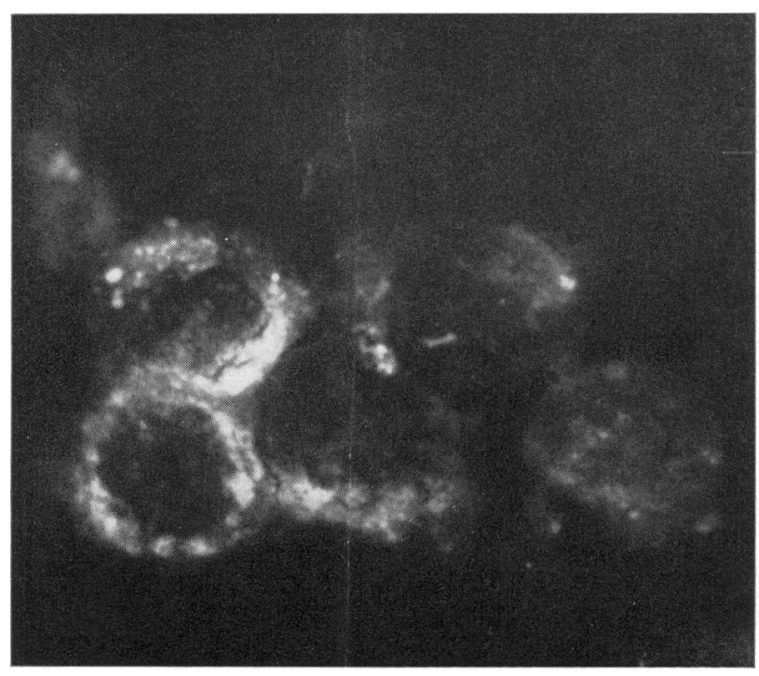

FIG. 2

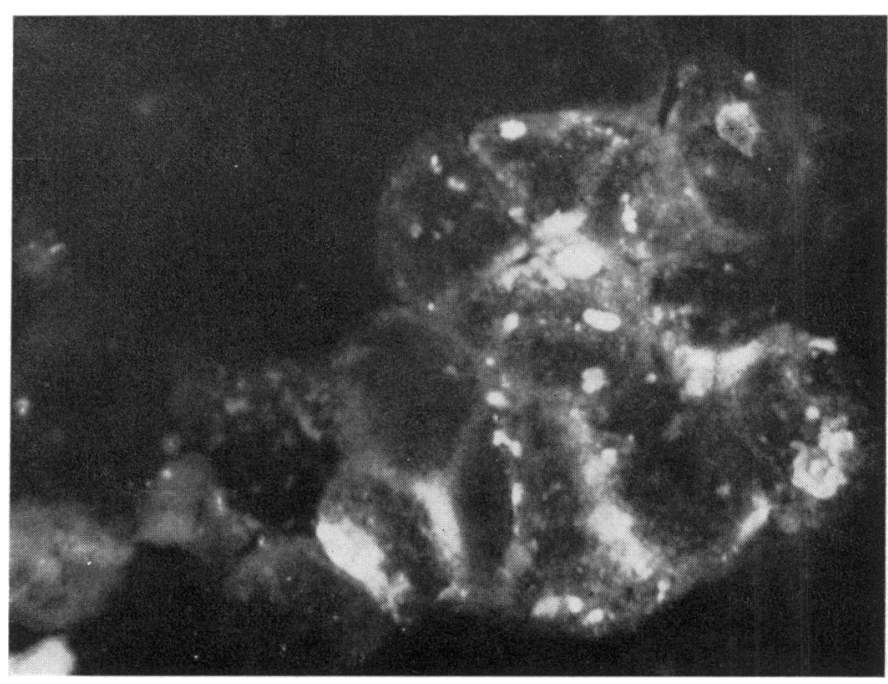

FIG. 3

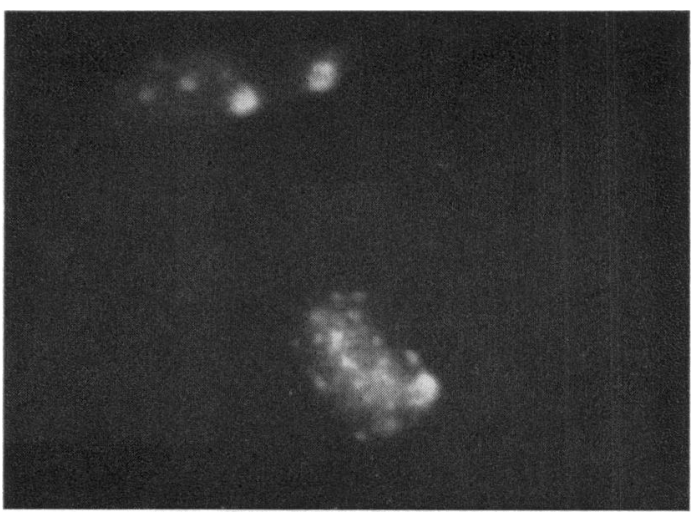

FIG. 6

FIGs. 4, 5, and 6.-These are examples of respiratory syncytial virus infected cells from nasopharyngeal secretions, showing specific particulate fluorescence and brilliantly fluorescing inclusion-like bodies. The figures also show the varied appearances of these cells. Staining method as for Figs. 1,2 , and $3 .(\times 500$.

Controls stained with normal rabbit serum and Fluoroscan Plus showed complete absence of fluorescence. 
fluorescent antibody technique can be safely used as a reliable substitute for the neutralization test.

Serology.-Paired sera were examined by the complement fixation test based on the method of Bradstreet and Taylor (1962), using a microtechnique. The sera were usually in very small quantities, and they were examined preferentially for the presence of respiratory syncytial virus antibodies before testing for other respiratory virus antibodies.

Specimens for Fluorescent Antibody Examination.-Cough swabs were inoculated into five tubes of Bristol HeLa and HEp.2 cells, three of which were examined by the fluorescent antibody technique within the first seven days and two were reserved for normal virus isolation: aspirated nasopharyngeal secretions were examined directly by the fluorescent antibody technique. Cough swabs and nasopharyngeal secretions were taken only from children under the age of 2 years, the majority being under the age of 1 year. The children would have been examined routinely for a virus aetiology and therefore had no special selection.

Preparation of Specimens for Examination by Immunofluorescent Technique.-(a) Nasopharyngeal Secretions-These were aspirated from the nasopharynx as previously described. It was found that in smears from secretions which were particularly thick and mucoid the stain may fail to penetrate to the cells in thick areas. Our technique was modified to overcome this difficulty. The secretion was emulsified in $0.5 \mathrm{ml}$. of saline, centrifuged, suspended in phosphate-buffered saline, and again centrifuged as before. The washed deposit was resuspended in a few drops of phosphate-buffered saline and half of the suspension was used to make two spots on a slide from the first wash. The remaining half of the suspension was resuspended in a further volume of phosphate-buffered saline and again centrifuged. The resultant twice-washed deposit was resuspended in a few drops of phosphate-buffered saline and two spots were placed on a slide from the second wash, which gave much thinner films. The slides from both washes were stained simultaneously. If the spot from the first wash was unsatisfactory on examination then the spot from the second wash was examined. (b) Tissue Culture-Cells from tissue culture tubes were scraped off and transferred to slides for staining. With very early positive tubes only a very small number of cells in the cell layer are infected. It was therefore necessary to place the vast majority of the cells from the tube in the spot to be tested with respiratory syncytial virus antiserum and use as small a volume of the suspension as adequately possible for the control spot to be tested with normal rabbit serum. In this way single positive cells could be observed at a very early stage. Negative cell controls were included for all batches of cells.

Immunofluorescent Staining Procedure-Indirect Method.-No changes were introduced into this procedure.

Fluorescent Microscopy.-Specimens were examined under darkground illumination by blue light, using (a) a Mazda ME/D 250 w. bench mercury vapour lamp and Vicker's Patholette II microscope with mirror, a $6-\mathrm{mm}$. blue Chance OB10 exciter filter, and a yellow barrier filter, or (b) a Wild M20 fluorescent microscope with an Osram HBO 200 mercury vapour lamp, a blue B.G. $12 / 4 \mathrm{~mm}$. exciter filter, and an OGI barrier filter.

Photography.-Photographs were taken with the Wild fluorescent microscope. Exposures varied from 160 to 180 seconds with an Ilford Mark V film.

\section{Results}

Table I denotes the clinical categaries of the children investigated and the examinations carried out.

TABLE I.-Investigations Carried Out on Various Clinical Categories

\begin{tabular}{|c|c|c|c|}
\hline Diagnosis & $\begin{array}{l}\text { Examination of } \\
\text { Nasopharyngeal } \\
\text { Secretions by } \\
\text { F.A. for R.S.V. }\end{array}$ & $\begin{array}{c}\text { Examination of } \\
\text { Inoculated Tissue } \\
\text { Culture by } \\
\text { F.A. for R.S.V. }\end{array}$ & $\begin{array}{c}\text { Suitably Paired } \\
\text { Sera for } \\
\text { Complement } \\
\text { Fixation Test }\end{array}$ \\
\hline $\begin{array}{lr}\text { Bronchiolitis } & \ldots \\
\text { Preumonia } & \because \\
\text { Bronchitis } & \because \\
\text { Croup . } & \text { Whooping-cough } \\
\end{array}$ & $\begin{array}{r}22 \\
7 \\
1 \\
3 \\
1 \\
\end{array}$ & $\begin{array}{r}37 \\
25 \\
5 \\
7 \\
1\end{array}$ & $\begin{array}{r}12 \\
10 \\
1 \\
1 \\
0\end{array}$ \\
\hline Total & 34 & $75^{*}$ & 24 \\
\hline
\end{tabular}

* Three omitted as specimens contaminated, but included in nasopharyngeal
secretions. secretions.

\section{Appearance of Fluorescing Respiratory Syncytial Virus Antigen}

At a very early stage in tissue culture cells the antigen appears as a scattering of very fine fluorescent dust-like particles in the cytoplasm of cells. At later stages the particles vary in size considerably and the fluorescence is much more intense. Most cells contain one or two large particles, spherical or boatshaped, resembling inclusion bodies, which fluoresce much more brilliantly than the others. This appearance is completely characteristic of respiratory syncytial virus infection, and in our experience the presence of only a single cell with this appearance is sufficient for a confident diagnosis. In tissue culture cells the presence of the brilliantly fluorescing inclusionlike bodies was taken as the criterion for respiratory syncytial virus infection: earlier stages were not accepted for diagnostic purposes (see Figs. 1-3, Special Plate).

In exfoliated cells from nasopharyngeal secretions the same particulate fluorescence is seen, mostly restricted to the cytoplasm. In the majority of cases the infected cells are present in sufficient numbers for a positive secretion to be recognized within minutes of examination under the microscope. There are usually one to three positive cells in every field. However, in a few cases the area of the spot had to be searched for some time before a positive cell was found. Even in such cases the positive cells, though few in number, were so characteristic in appearance that an accurate diagnosis could be made. A false-positive has not been observed. Figs. 4-6 (Special Plate) illustrate typical examples of positive nasopharyngeal cells.

\section{Examination of Nasopharyngeal Secretions}

Table II shows both the number of positive nasopharyngeal secretions and the correlation of positive fluorescent antibody results with respiratory syncytial virus isolations. It is now known that the majority of cases of bronchiolitis are caused by respiratory syncytial virus, and it is considered worth while to detail the seven cases of bronchiolitis which gave negative fluorescent antibody results.

TABLE II.-Nasopharyngeal Secretions Examined for Respiratory Syncytial Virus (R.S.V.) by Fluorescent Antibody (F.A.) Technique Compared with Isolatzons

\begin{tabular}{|c|c|c|c|c|c|}
\hline \multirow{2}{*}{ Diagnosis } & \multirow{2}{*}{$\begin{array}{c}\text { No. of } \\
\text { Naso- } \\
\text { pharyngeal } \\
\text { Secretions } \\
\text { Examined }\end{array}$} & \multicolumn{2}{|c|}{$\begin{array}{l}\text { R.S.V } \\
\text { Culture Positive }\end{array}$} & \multicolumn{2}{|c|}{$\begin{array}{l}\text { R.S.V. } \\
\text { Culture Negative }\end{array}$} \\
\hline & & $\begin{array}{c}\text { F.A. } \\
\text { Positive }\end{array}$ & $\begin{array}{c}\text { F.A. } \\
\text { Negative }\end{array}$ & $\begin{array}{c}\text { F.A. } \\
\text { Positive }\end{array}$ & $\begin{array}{c}\text { F.A. } \\
\text { Negative }\end{array}$ \\
\hline $\begin{array}{ll}\text { Bronchiolitis } & \ldots \\
\text { Pneumonia } & \ldots \\
\text { Bronchitis } & \ldots \\
\text { Croup } & \\
\text { Whooping-cough }\end{array}$ & $\begin{array}{r}22 \\
7 \\
1 \\
3 \\
1\end{array}$ & $\begin{array}{r}15 \\
2 \\
0 \\
0 \\
0\end{array}$ & $\begin{array}{l}1 \\
1 \\
0 \\
0 \\
0\end{array}$ & $\begin{array}{l}\mathbf{0} \\
0 \\
0 \\
0 \\
0\end{array}$ & $\begin{array}{l}6 * \\
4 * \\
1 \\
3 \\
1\end{array}$ \\
\hline Total & 34 & 17 & 2 & 0 & 15 \\
\hline
\end{tabular}

* Parainfluenza III and E.C.H.O. virus type 19 isolated from two children with bronchiolitis and adenovirus type 4 isolated from one child with pneumonia. Bronchiolitist-Copositivity: $15 / 16=94 \%$. Conegativity: $6 / 6=100 \%$. Overal agreement: $21 / 22=95 \%$.

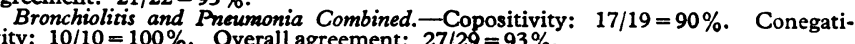
vity: $10 / 10=100 \%$. Overall agr
+ After Buck and Gart (1966).

Case 1.-Respiratory syncytial virus was isolated from the nasopharyngeal secretion on the eighth day. This was the first case in the series, and, owing to inexperience, the nasopharyngeal secretion stood at $+4^{\circ} \mathrm{C}$. for seven hours before it was prepared. All specimens are now dealt with immediately.

Case 2.-E.C.H.O. virus type 19 was isolated from both the nasopharyngeal secretion and the cough swab. Though serologically the child had a fourfold rising titre to respiratory syncytial virus, the presence of E.C.H.O. virus type 19 in the nasopharyngeal secretion may have interfered with respiratory syncytial virus.

Case 3.- Specimens from this child were negative to respiratory syncytial virus in tissue culture of both cough swab and nasopharyngeal secretion. Parainfluenza III was isolated. The acute bronchiolitis in this case was almost certainly caused by this virus, and respiratory syncytial virus would not then be found. 
Cases 4, 5, 6, and 7.-These were all negative by immunofluorescent techniques in both tissue culture and nasopharyngeal secretion, nor was respiratory syncytial virus isolated from the specimens. These were probably true negatives with an alternative, but unknown, aetiology.

\section{Examinaion of Inoculated Tissue Culture Cells}

Table III shows the results of examination of tissue culture cells and the correlation of positive fluorescent antibody results

TABLB III.-Comparison of Fluorescent Antibody with Isolation and

\begin{tabular}{|c|c|c|c|c|c|c|c|}
\hline \multirow[t]{2}{*}{ Diagnosis } & \multirow[t]{2}{*}{$\begin{array}{l}\text { No. of } \\
\text { Cases } \\
\text { Exam- } \\
\text { ined }\end{array}$} & \multicolumn{3}{|c|}{$\begin{array}{c}\text { Day Tissue Culture } \\
\text { Tube First } \\
\text { Positive by F.A. }\end{array}$} & \multirow{2}{*}{$\begin{array}{c}\text { Tissue } \\
\text { Culture } \\
\text { Negative } \\
\text { by } \\
\text { F.A. }\end{array}$} & \multicolumn{2}{|c|}{$\begin{array}{l}\text { R.S.V. Culture or } \\
\text { Serological } \\
\text { Evidence of R.S.V }\end{array}$} \\
\hline & & 2 & 4 & 7 & & Positive & Negative \\
\hline $\begin{array}{lr}\text { Bronchiolitis } & \ldots \\
\text { Pneumonia } & \ldots \\
\text { Bronchitis } & \ldots \\
\text { Croup } & \text { Whooping-cough }\end{array}$ & $\begin{array}{r}37 \\
25 \\
5 \\
7 \\
1\end{array}$ & $\begin{array}{r}16 \\
6 \\
1 \\
0 \\
0\end{array}$ & $\begin{array}{l}\mathbf{7} \\
1 \\
0 \\
0 \\
0\end{array}$ & $\begin{array}{l}2 \\
3 \\
0 \\
0 \\
0\end{array}$ & $\begin{array}{c}12 * \\
15^{*} \\
4 \\
7 \\
1\end{array}$ & $\begin{array}{c}30+ \\
13 \dagger \\
1 \\
0 \\
0\end{array}$ & $\begin{array}{r}7 \\
12 \\
4 \\
7 \\
1\end{array}$ \\
\hline Total & 75 & 23 & 8 & 5 & 39 & 44 & 31 \\
\hline
\end{tabular}

- Three children, two with bronchiolitis and one with pneumonia, omitted from F.A. tube method because of contamination of throat swab but included in nasopharyngeal secretion cultures (Table II) which were not contaminated.

t Virus isolation failed in only two children with positive fluorescent antibody tissue culture tubes, one with pneumonia and one with bronchiolitis: both had ourfold rising titres of antibody to respiratory syncytial virus.

Bronchiolitis.-Copositivity: $25 / 30=83 \%$. Conegativity: $7 / 7=100 \%$. Overall agreement: $32 / 37=87 \%$.

: $10 / 13=77 \%$. Conegativity: $12 / 12=100 \%$. Overall agreement: $22 / 25=92 \%$. vity: $19 / 19=100 \%$. Overall agreement: $54 / 62=87 \%$.

with respiratory syncytial virus isolation. The relatively lower percentages for copositivity with acute bronchiolitis in this method are related to late culture of respiratory syncytial virus, and the negative fluorescent antibody tubes probably reflect a small virus inoculum initially.

\section{Serological Results and Immunofluorescence}

Table IV summarizes the relation between the examination of paired sera and the immunofluorescent technique, both in tissue culture and in nasopharyngeal secretions. A statistical correlation has been attempted, though the number of paired sera received was small, and though a variable antibody response may be expected to occur in the sera of very young children.

TABLE IV.-Relation of Antibody to Respiratory Syncytial Virus in 24

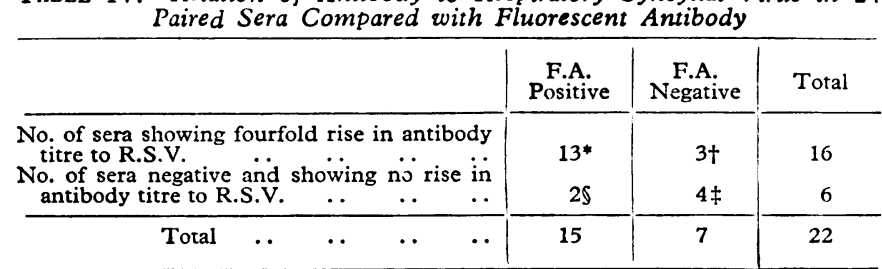

Two additional sera were negative but associated with contaminated tissue culture and are not included in Table. In both cases the nasopharyngeal secretions were
fluorescent antibody negative and respiratory syncytial virus was not isolated from them.

*All except two had respiratory syncytial virus isolated (see " Cases of Special Interest " and "Discussion").

t One was associated with respiratory syncytial virus isolation of the 28 th day and had infection with influenza A (see "Cases of Special Interest") and one was associated with E.C.H.O. virus type 19 isolation (see Case 2 under Table II).

$\ddagger$ One associated with respiratory syncytial virus isolation (see Case 1 under Table II).

Both associated with respiratory syncytial virus isolation.

Copositivity: $13 / 16=81 \%$. Conegativity: $4 / 6=67 \%$. Overall agreement $17 / 22=77 \%$.

\section{Cases of Special Interest}

(1) There was evidence of dual infection in a 3-months-old child with pneumonia. Influenza A was isolated from this child, and respiratory syncytial virus was also isolated at a very late stage. Fourfold rising antibody titres were obtained both to influenza $\mathrm{A}$ and to respiratory syncytial virus.
(2) Two children, one aged 5 months with pneumonia and one aged 6 months with acute bronchiolitis, showed positive fluorescence in tissue culture on both day 2 and day 4 , but a decrease in fluorescence on day 6 . In neither case was a virus isolated, but both children had a fourfold rising antibody titre to respiratory syncytial virus. The second patient was a twin, and from the other twin, who was ill with acute bronchiolitis at the same time, respiratory syncytial virus was isolated and a fourfold rise in antibody titre to respiratory syncytial virus was obtained.

(3) E.C.H.O. virus type 19, parainfluenza virus type III, and adenovirus type 4 were isolated from three nasopharyngeal secretions respectively. None showed positive immunofluorescence for respiratory syncytial virus.

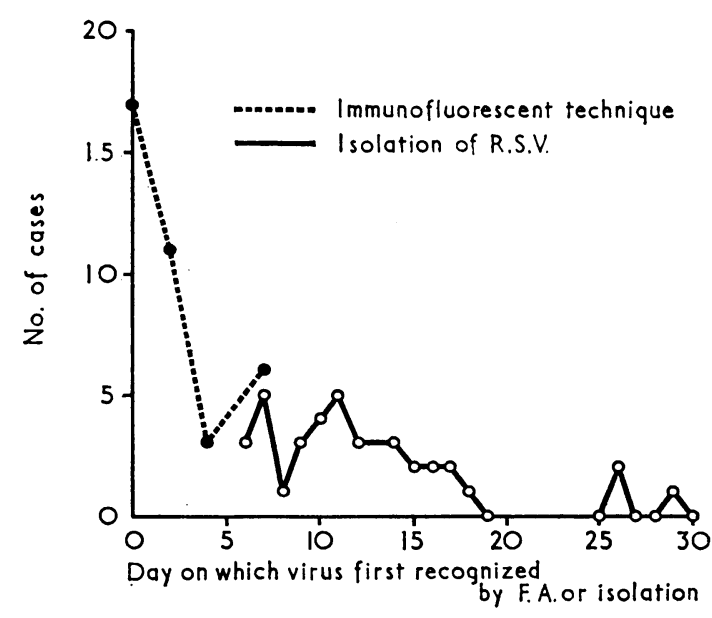

FIG. 7.-Comparison of diagnosis times by immunofluorescence and isolation techniques.

Fig. 7 shows the comparison of the diagnosis times by immunofluorescent and isolation techniques.

\section{Discussion}

Before the introduction of a new technique its reliability must be established beyond doubt. The first factor in reliability is the ease of recognition by the observer, and we have attempted to describe and illustrate (Figs. 1 to 6, Special Plate) the typical appearance of specific respiratory syncytial virus intracellular fluorescence, both in tissue culture cells and in exfoliated cells in nasopharyngeal secretions. The appearances in tissue culture cells were identical with those described by Bennett and Hamre (1962) and Kisch et al. (1962).

The presence of a sufficient number of undamaged cells in the material is an equally important factor, and this we have achieved by aspirating nasopharyngeal secretions and by using tissue cultures inoculated with material taken from the patient. In contrast with others, we have abandoned smears from throat swabs, as, in our hands, they are a poor and unreliable source of intact cells.

We have assessed the reliability of the test by comparing immunofluorescent techniques with isolation techniques and serological examination of patients' sera for the development of antibody, the conventional methods of identifying virus infection. By the continuous improvement of our isolation techniques over the years (Andrew and Gardner, 1963 ; Elderkin et al., 1965 ; Holdaway et al., 1967) the percentage of successful isolations of respiratory syncytial virus from suspected cases has steadily increased but is still not a complete index. Serological techniques, though reliable, must be based on a fourfold increase in antibody titre, but in the infant population which is being considered the sensitivity of the test may be reduced (Parrott et al., 1961 ; Gardner et al., 1964). 
As long ago as 1960 we attempted to define the clinical categories of acute childhood respiratory disease; the absence of virus isolation only from children with acute bronchiolitis in the period before techniques for respiratory syncytial virus isolation were available (Gardner et al., 1960) confirmed the accuracy of the classification. Our previous work and that of others (Chanock et al., 1961 ; Holzel et al., 1963) has confirmed the respiratory, syncytial virus is the major cause of acute bronchiolitis and an important agent in many cases of pneumonia, and it is for this reason that we have concentrated on these two clinical categories. Moreover, nasopharyngeal secretions were more likely to be abundant in these two conditions. Concern has been expressed by Miller and Taylor (1968) and Gardner and McQuillin (1968) at the lack of correlation between conventional methods and the fluorescent antibody techniques used by Gray et al. The explanation of their discrepancies may well lie in the unsuitability of throat-swab smears as a source of intact cells for immunofluorescence. In our series both infected tissue cultures and nasopharyngeal secretions show a good correlation with conventional techniques. Moreover, by separating our patients into the clinical categories of acute bronchiolitis and pneumonia we have obtained the same proportion of cases with a respiratory syncytial virus aetiology as we have by isolation techniques, both in the current series and in our previous work.

The results obtained and their correlation with conventional isolation and serological techniques are shown in Tables II, III, and IV, and the methods of Buck and Gart (1966) were used to substantiate this relationship. Copositivity is a measure of sensitivity, while conegativity is a measure of specificity. The specificity of this method is extremely high when compared with the results of examination of nasopharyngeal secretions, tissue cultures, and sera by conventional means. The copositivity is highest in nasopharyngeal secretions but lower when applied to tissue culture cells, and this coincides with an increase in time taken for conventional isolation. It suggests that some of the tissue culture tubes are negative by immunofluorescent techniques because the original virus inoculum was too small to be detected in seven days. One nasopharyngeal secretion from a child with bronchiolitis was negative by the fluorescent antibody technique and positive by culture; this was the first nasopharyngeal secretion to be examined, and the material had been stored for seven hours before preparation. Respiratory syncytial virus was isolated after 26 days from another negative nasopharyngeal secretion by the fluorescent antibody technique, suggesting that there was little infective material present in the secretion initially.

No specific fluorescence to respiratory syncytial virus was found in three nasopharyngeal secretions where other viruses were present, further confirming the specificity of the test. However, one of these cases excreting E.C.H.O. virus type 19 later developed a fourfold rising antibody titre to respiratory syncytial virus. This may be an example of interference with respiratory syncytial virus by another virus, resulting in the absence of positive direct fluorescence to respiratory syncytial virus. Another possible example of interference is in the child with pneumonia associated with influenza $A$ : a fourfold rising titre to influenza A virus and also to respiratory syncytial virus was obtained with a very late respiratory syncytial virus isolation at 28 days. Again there was no direct fluorescence to respiratory syncytial virus in tissue culture in the first seven days. Unfortunately, no nasopharyngeal secretion was available from this patient. It could be argued, however, that both these cases were examples of hospital cross-infection.

Respiratory syncytial virus is subject to various inhibiting factors in tissue culture which create difficulties in its isolation (Jordan, 1962). Two cases showed early specific fluorescence in tissue culture, but this declined by the seventh day and no virus was isolated. However, both children had a fourfold rising antibody titre to respiratory syncytial virus, and one child's twin, ill with bronchiolitis at the same time, not only had a fourfold rising titre of antibody to respiratory syncytial virus, but the virus was isolated. This illustrates that specific fluorescence, even at day 2 , may on occasion be more sensitive than virus isolation.

The immunofluorescent technique, as shown in Fig. 7, has revolutionized the time in which a positive report can be expected. Sixty-nine per cent. of children with bronchiolitis were diagnosed as suffering from respiratory syncytial virus infection on the day of admission. There were 44 children with respiratory syncytial virus infection diagnosed by conventional methods spread over a period of a month, but by using immunofluorescent techniques on tissue culture cells $53 \%$ were found positive on the second day, $71 \%$ on the fourth day, and $82 \%$ on the seventh day. There is no doubt that the method of choice for rapid diagnosis is by using nasopharyngeal secretions: in this series a diagnosis in over $90 \%$ of those with a respiratory syncytial virus infection was made on the day of admission. It must be emphasized that reagents used for this technique must be completely specific, and all work of this nature must be stringently controlled to avoid non-specific reactions which can be mistaken for positives. The reliability of fluorescent antibody techniques depends on the presence of an adequate number of intact cells in the preparation showing specific intracellular fluorescence. Grave damage may be done to diagnostic virology by the indiscriminate use of inadequately controlled tests and reagents.

Because of the large number of cells present in nasopharyngeal secretions it will no doubt be possible to screen simultaneously against other viruses when the appropriate sera for use in this technique are available.

During last winter the clinicians in this and other hospitals in the area had been assisted in the management of cases of bronchiolitis by rapid and accurate diagnosis of respiratory syncytial virus infection within 24 hours of admission.

We believe this method will become an essential preliminary for successful antiviral therapy.

We wish to thank Professor S. D. M. Court, his clinical colleagues, and their ward sisters and medical staff at all the hospitals for their collaboration. We are indebted to Miss P. M. Sturdy for the collection of specimens; to Dr. D. L. Miller, of the Central Public Health Laboratory, Colindale, for his assistance with the presentation of the statistical analysis; and to Mr. R. S. Gilder, of the Department of Photography, the University of Newcastle upon Tyne, for his advice. Special thanks are due to the Scientific and Research Subcommittee of the Royal Victoria Infirmary and to the Medical Research Council for grants which made this work possible. We also wish to thank Winthrop Biologicals Limited for their reagents.

\section{REFERENCES}

Andrew, J. D., and Gardner, P. S. (1963). Brit. med. f., 2, 1447. Bennett, C. R., jun., and Hamre, D. (1962). F. infect. Dis., 110, 8. Bradstreet, C. M. P., and Taylor, C. E. D. (1962). Mth. Bull. Minist. Hlth Lab. Serv., 21, 96.

Brighton, W. D. (1966). f. clin. Path., 19, 456.

Buck, A. A., and Gart, J. J. (1966). Amer. f. Epidem., 83, 586.

Chanock, R.' M., et al. (1961). f. Amer. med. Ass., 176, 647.

Elderkin, F. M., Gardner, P. S., Turk, D. C., and White, A. C. (1965). Brit. med. f., 2, 722 .

Gardner, P. S., Elderkin, F. M., and Wall, A. H. (1964). Brit. med. F., 2,1570 .

Gardner, P. S., and McQuillin, J. (1968). Lancet, 1, 597.

Gardner, P. S., Stanfield, J. P., Wright, A. E., Court, S. D. M., and Green, C. A. (1960). Brit. med. F., 1, 1077.

Gray, K. G., MacFarlane, D. E., and Somerville, R. G. (1968). Lancet, $1,446$.

Hers, J. F. P., van der Kuip, L., and Masurel, N. (1968). Lancet, 1, 510. Holdaway, D., Romer, A. C., and Gardner, P. S. (1967). Pediatrics, 39,

924.
Holzel, A., Parker, L., Patterson, W. H., White, L. L. R., Thompson, K. M., and Tobin, J. O'H. '(1963). Lancet, 1, 295.

Jordan, W. S., jun. (1962). f. Immunol., 88, 581 .

Kisch, A. L., Johnson, K. M., and Chanock, R. M. (1962). Virology, 16. 177 .

McQuilin, J., and Gardner, P. S. (1968). Brit. med. f., 1, 602.

Miller, D. L., and Taylor, C. E. D. (196i). Lancet, 1, 697.

parrott, R. H., et al. (1961). f. Amer. med. Ass., 176, 653. 